\title{
STRATEGI PENGEMBANGAN SEKTOR INDUSTRI KECIL KOTA TARAKAN
}

\author{
STRATEGY FOR SMALL INDUSTRY SECTOR DEVELOPMENT \\ IN TARAKAN CITY
}

\author{
Muhammad Andra Fahreza Zulkarnain ${ }^{1)}$, Asih Kusuma Wijayanti ${ }^{2)}$, \\ ${ }^{1) 2) 3)}$ Universitas Borneo Tarakan
}

\begin{abstract}
Abstrak : Banyak potensi yang dapat di kembangkan di Tarakan di antaranya pada sector kelautan dan perikanan, sector pariwisata, industri dan perdagangan serta investasi di sector energi. Dengan berbagai potensi tersebut peluang pengembangan UMKM di Kota Tarakan Provinsi Kalimantan Utara menjadi strategis. Posisi Wilayah Kalimantan Utara yang berbatasan langsung dengan negara jiran Malaysia, menjadikan UMKM harus berbenah diri dalam meningkatkan daya saingnya terlebih lagi dengan pemberlakuan perdagangan bebas pada ASEAN Economic Community (AEC) sejak tahun 2015. Untuk itu strategi pengembangan usaha bagi UMKM perlu dirumuskan dan dapat menjadi rekomendasi bagi pemerintah dan stakeholder lainnya dalam membuat kebijakan pemberdayaan UMKM di Kota Tarakan. (Ariani, Utomo. 2017). Tujuan penelitian yaitu untuk mengetahui strategi pengembangan sektor industri kecil di Kota Tarakan. Objek penelitian ini adalah industry kecil di Kota Tarakan menurut jenis usaha. Perumusan strategi pengembangan industri kecil di Kota Tarakan perlu adanya identifikasi mengenai kekuatan dan kelemahan sebagai faktor internal dan faktor eksternal berupa peluang dan ancaman. Dari hasil olah data diketahui bahwa posisi kuadran industri kecil di Kota Tarakan terletak di kuadran 1 atau terletak antara peluang eksternal dan kelemahan internal. Berdasarkan posisi kuadrannya, strategi yang digunakan adalah strategi SO ( Strength - Opportunity), yaitu strategi yang meminimalkan kelemahan dan memanfaatkan peluang. Alternatif strategi SO yang dirumuskan adalah sebagai membuat akun media sosial untuk mempermudah promosi dalam penjualan produk. Di zaman yang modern dan serba memanfaatkan kecanggihan teknologi, media sosial yang beragam saat ini dapat dijadikan sebagai alat untuk melakukan promosi. Media sosial menjadi salah satu alat promosi yang efektif karena dapat secara langsung memberikan infromasi kepada pasar penjualan hasil produksi industri kecil. Selain itu membuka cabang di luar wilayah industri. Dengan membuka cabang usaha di wilayah lain akan meningkatkan produksi dan cakupan wilayah pemasaran hasil industri kecil.
\end{abstract}

Kata Kunci: Analisis SWOT, Industri Kecil, Strategi Pengembangan.

Abstract : A lot of potential can be developed in Tarakan in the marine and fisheries sector, industry, trade and investment in the energy sector. With various potential opportunities for the development of MSMEs in Tar akan City, North Kalimantan Province becomes strategic. The position of North Kalimantan Region which is directly adjacent to the neighboring country of Malaysia, has 
made MSMEs have to improve themselves in increasing their competitiveness even more so wi th the implementation of free trade in the ASEAN Economic Community (AEC) since 2015. For that reason, business development strategies for MSMEs need to be bust and can become stakeholders and other stakeholders in making policies on empowering MSMEs in Ta rakan City. (Ariani, Utomo. 2017). The research objective is to find out the development strategy of the small industrial sector in Tarakan City. The object of this study is a small industry in the city of Tarakan by type of business. The formulation of $s$ mall industry development strategies in Tarakan City is necessary. And external factors. From the results, the data available for small companies in Tarakan City is located on one or one internal channel. Based on the quadrant position, the strategy is the SO strategy (Strength - Opportunity), which is a strategy that seeks weaknesses and seizes opportunities. The alternative formulated SO strategy is to create a social media account to facilitate promotion in product sales. In a modern and versatile era util izing technological sophistication, different social media can now be used as a tool for promotion. Social media is one of the effective promotional tools because it can provide information to the market selling small industrial products. Besides opening $b$ ranches outside the industrial area. Opening branches in other regions will increase production and display of smallscale industrial output areas.

Keywords: SWOT Analysis, Small Industry, Strategy Development.

\section{LATAR BELAKANG}

Proses pembangunan suatu negara sering pula dikaitkan dengan proses industrialisasi. Proses industrialisasi merupakan salah satu perantara menuju proses pembangunan yang baik dan dapat meningkatkan taraf hidup masyarakat dengan memperluas kesempatan bekerja bagi masyarakat. Industri kecil dan menengah memiliki prospek yang positif untuk terus dikembangkan, sehingga dapat membantu mengurangi tingkat pengangguran. (Siburian, Woyanti, 2013). Industri kecil menempati posisi strategis dalam perekonomian di Indon esia yang tidak diragukan lagi. Sektor industri kecil merupakan salah satu lokomotif yang krusial bagi pembangunan dan pertumbuhan ekonomi banyak di negara di dunia.
Pengembangan industri ditujukan agar industri tersebut dapat selalu terjaga kelangsungan produksinya sehingga pengusaha akan tetap bertahan dalam industri tersebut. (Gumelar, dkk. 2015). Industri kecil tidak terlepas dari peranan para pengusaha (entrepreneur) yang bergerak di dalamnya. Pengusaha ini yang akan memunculkan, mempertahankan dan ju ga mengembangkannya. Astamoen (2008) mengemukakan bahwa "dengan banyaknya entrepreneur , dua indikator penting di dalam suatu negara maju dan makmur terpenuhi, yaitu rendahnya angka pengangguran dan tingginya devisa yang terutama dari hasil barang - barang ekspor yang dihasilkan". Peran para entrepreneur dalam memajukan perekonomian dan peningkatantaraf hidup masyarakat di dalam suatu 
negara sangat penting. Kemajuan ekonomi harusnya sejalan dengan kemampuan serta peningkatan daya beli, peningkatan taraf hidup masyarakat, kemakmuran bangsa yang dirasakan secara nyata dan tidak hanya sekedar pada data dan angka statistik saja. Selanjutnya Astamoen (2008) mengemukakan bahwa, salah satu penyebab lambatnya pertumbuhan ekonomi di Indonesia adalah masih sedikitnya $j$ umlah entrepreneur sebagai pelaku ekonomi, antara lain pengusaha, pedagang, industrialis dan lain - lain. Kota Tarakan sebagai kota pendidikan, perdagangan dan jasa dimana struktur perekonomian Kota Tarakan tidak lagi didominasi oleh usaha berbasis sumberdaya alam, melainkan didominasi usaha sekunder dan tersier, hal ini terlihat dari besarnya peranan masing masing Industri terhadap pembentukan PDRB Kota Tarakan. Sumbangan terbesar pada tahun 2015 dihasilkan oleh Industri Perdagangan Besar dan Eceran ; Reparasi Mobil dan Motor (21,21\%), Industri Konstruksi $\quad(14,60 \%), \quad$ Industri Transportasi dan Pergudangan (13,52\%); Industri Pengolahan, Industri Pertanian, Kehutanan dan Perikanan, dimana masing - masing memberikan kontribusi lebih dari 10 persen, sedangkan kategori Industri lainnya peranan kurang dari 8 persen. (BPS Kota Tarakan, 2017).

\section{RUMUSAN MASALAH}

Berdasarkan latar belakang di
atas maka rumusan masalah
penelitian ini adalah bagaimana
strategi pengembangan sektor
industri kecil di Kota Tarakan.

\section{TUJUAN PENELITIAN}

Tujuan penelitian yaitu untuk mengetahui strategi pengembangan sektor industri kecil di Kota Tarakan.

\section{TINJAUAN TEORITIS}

\section{$\underline{\text { Konsep Strategi }}$}

Pada dasarnya strategi adalah sesuatu hal atau kegiatan untuk menciptakan suatu posisi yang unik dan bernilai yang melibatkan berbagai aktifitas perusahaan dan strategi memberikan pilihan tentang apa yang harus dilakukan serta apa yang tidak perlu dilakukan (Porter, 2003). Selanjutnya Porter dalam Rangkuti (2004) berpendapat bahwa strategi adalah alat yang sangat penting untuk mencapai keunggulan bersaing. Sedangkan menurut Chandler dalam Rangkuti (2015) strategi adalah tujuan jangka panjang dari suatu perusahaan, serta pendayagunaan dan alokasi semua sumber daya yang penting untuk mencapai tujuan tersebut.

\section{Analisis SWOT (Strength, Weakness, Opportunity, and Threat)}

Analisis SWOT merupakan bagian dari proses perencanaan. Hal utama yang ditekankan adalah bahwa dalam proses perencanaan tersebut, suatu institusi membutuhkan penilaian mengenai kondisi saat ini dan gambaran ke depan yang mempengaruhi proses pencapaian tujuan institusi. Dengan analisis SWOT akan didapatkan karakteristik dari kekuatan utama, kekuatan tambahan, faktor netral, kelemahan 
utama dan kelemahan tambahan berdasarkan analisa lingkungan internal dan eksternal yang dilakukan.

Metode analisis SWOT digunakan untuk menyusun strategi pembangunan. Rangkuti dalam Mulyadi (2007) menjelaskan bahwa analisis SWOT merupakan identifikasi berbagai faktor secara sistematik untuk merumuskan strategi, analisis ini didasarkan pada logika yang dapat memaksimalkan kekuatan (strength) dan peluang (opportunity), namun secara bersamaan dapat meminimalkan kelemahan (weakness) dan ancaman (threat).

Menurut Finlay, dalam Heene dkk (2010), analisis-analisis yang menggunakan pendekatan SWOT ini merupakan suatu bentuk lompatan pemikiran yang menawan bagi upaya merumuskan strategi apa yang diperlukan karena mampu mendeteksi kelemahan-kelemahan organisasi yang manakah perlu diperkuat, serta penguatan-penguatan seperti apa yang dapat diupayakan untuk menciptakan nilai. Lalu, peluang-peluang manakah yang memang berguna untuk dimanfaatkan oleh organisasi, dan dicermati mana yang merupakan ancaman-ancaman dimana organisasi perlu bersiap-siap mempersenjatai diri untuk menghadapinya.

Sedangkan menurut Marimin dalam Mulyadi (2007), analisis SWOT mempertimbangkan faktor lingkungan internal kekuatan (strength) dan kelemahan (weakness) serta lingkungan eksternal (opportunity) dan ancaman (threat) yang dihadapi. Analisis SWOT membandingkan antara faktor-faktor internal dan eksternal sehingga dari analisis tersebut dapat diambil suatu keputusan strategi. Analisis SWOT mencakup tiga langkah utama, yaitu:

a. Memahami kekuatan dan kelemahan lingkungan internal.

b. Mempelajari lingkungan dan memahami peluang serta ancaman yang ada dalam lingkungan eskternal.

c. Menganalisis kekuatan mana yang dapat digunakan untuk mengambil keuntungan dari peluang yang khusus, dan kelemahan mana yang dapat membuat rawan pada saat menghadapi ancaman tertentu, sehingga dapat merencanakan opsi strategis yang lebih baik.

2. Fakor Internal dan Eksternal

Faktor internal adalah faktorfaktor yang meliputi kekuatan dan kelemahan. Menurut Pearce dan Robinson (2008), kekuatan merupakan sumber daya atau kapabilitas yang dikendalikan atau tersedia bagi suatu perusahaan yang membuat perusahaan relatif lebih unggul dibanding dengan pesaingnya. Sedangkan kelemahannya adalah keterbatasan atau kekuarangan dalam satu atau lebih sumber daya suatu perusahaan terhadap pesaingnya.

Sedangkan faktor eksternal adalah faktor yang meliputi peluang dan ancaman. Menurut Pearce dan Robinson (2008), peluang merupakan situasi utama yang menguntungkan pada lingkungan suatu perusahaan, sedangkan ancaman adalah situasi utama yang tidak menguntungkan pada lingkungan suatu perusahaan. 


\section{METODOLOGI PENELITIAN}

Pada penelitian ini digunakan desain penelitian kualitatif yang yang disesuaikan dengan situasi dan kondisi yang ada di lapangan. Hal - hal yang memungkinkan desain penelitian berubah termasuk: tujuan, subyek, sampel penelitian dan sumber data. Objek penelitian ini adalah industri kecil di Kota Tarakan menurut jenis usaha. Penelitian ini dilakukan di wilayah Kota Tarakan, Waktu pelaksanaan penelitian adalah bulan Juni - Juli 2018. Populasi sekaligus sampel pada penelitian ini yaitu seluruh industri kecil yang ada di Kota Tarakan pe riode tahun 2016 berdasarkan jenis usaha dengan jumlah 55 .

Analisis SWOT adalah identifikasi berbagai faktor secara sistematis untuk merumuskan strategi. Analisis ini didasarkan pada logika yang dapat memaksimalkan kekuatan ( strength) dan peluang ( opportun ity ), namun secara bersamaan dapat meminimalkan kelemahan ( weakness ) dan ancaman ( threat ). Hal ini disebut dengan analisis situasi. Model yang paling populer untuk analisis situasi adalah analisis SWOT (Rangkuti, 2006).

Setelah mengumpulkan informasi yang berpengaruh terhadap kelangsungan pengembangan industri kecil di Kota Tarakan, tahap selanjutnya adalah memanfaatkan informasi tersebut ke dalam rumusan strategi. Alat yang digunakan untuk menyusun faktor-faktor strategis pengembangan adalah matrik SWOT. Matrik ini dapat menggambarkan secara jelas bagaimana peluang dan ancaman eksternal yang dihadapi industri kecil di Kota Tarakan dapat disesuaikan dengan kekuatan dan kelemahan internal yang dimilikinya. Matrik analisis SWOT menghasilkan empat set kemungkinan alternatif strategi.

\section{HASIL PEMBASAHAN}

Analisis

SWOT membandingkan antara faktor faktor internal (kekuatan dan kelemahan) dan eksternal (peluang dan ancaman) sehingga dari analisis tersebut dapat diambil suatu keputusan strategi. Dalam penyusunan strategi pengembangan industri kecil di Kota Tarakan, terlebih dahulu diidentifikasi faktor kekuatan, kelemahan, peluang dan ancamannya.

1. Matrik Faktor Strategi Internal (IFAS) Matriks IFAS menggambarkan bagaimana faktor - faktor internal dipertimbangkan oleh suatu ruang terbuka publik untuk merumuskan strategi d alam meningkatkan kualitas pengelo laannya

2. Matrik Faktor Strategi Eksternal (EFAS) Matriks EFAS menggambarkan bagaimana faktor - faktor eksternal dipertimbangkan oleh suatu ruang terbuka publik untuk merumuskan strategi dalam meningkatkan kualitas pengelolaannya.

Berdasarkan hasil yang diperoleh dari matriks analisis SWOT maka dihasilkan strategi SO, WO, ST dan WT adapun strategi yang dihasilkan yaitu: 
1. Strategi SO (StrengthOpportunity), strategi yang menggunakan kekuatan dan memanfaatkan peluang.

a. Membuat akun media sosial untuk mempermudah promosi dalam penjualan produk

b. Membuka cabang di luar wilayah industri

2. Strategi WO (WeaknessOpportunity), strategi yang meminimalkan kelemahan dan memanfaatkan peluang.
a. Memperluas wilayah pemasaran hasil produksi industri kecil
b. Memperbaiki sistem keuangan agar lebih jelas
c. Membuat varian produk sesuai tren pasar

3. Strategi ST (Strength-Threats), strategi yang menggunakan kekuatan dan mengatasi ancaman.

a. Membuat produk yang memiliki ciri khas tersendiri

b. Memperbesar usaha industri

4. Strategi WT (Weakness-Threats), strategi yang meminimalkan kelemahan dan menghindari ancaman.

a. Memiliki pemasok bahan baku tetap lebih dari satu

b. Menyediakan stok hasil produksi secara berkala

Perumusan strategi pengembangan industri kecil di Kota Tarakan perlu adanya identifikasi mengenai kekuatan dan kelemahan sebagai faktor internal dan faktor eksternal berupa peluang dan ancaman. Dari hasil olah data diketahui bahwa posisi kuadran industri kecil di Kota Tarakan terletak di kuadran 1 atau terletak antara peluang ekternal dan kelemahan internal. Berdasarkan posisi kuadrannya, strategi yang digunakan adalah strategi SO (Strength-Opportunity), yaitu strategi yang meminimalkan kelemahan dan memanfaatkan peluang. Alternatif strategi SO yang dirumuskan adalah sebagai berikut:

1. Membuat akun media sosial untuk mempermudah promosi dalam penjualan produk. Di zaman yang modern dan serba memanfaatkan kecanggihan teknologi, media sosial yang beragam saat ini dapat dijadikan sebagai alat untuk melakukan promosi. Media sosial menjadi salah satu alat promosi yang efektif karena dapat secara langsung memberikan infromasi kepada pasar penjualan hasil produksi industri kecil.

2. Membuka cabang di luar wilayah industri. Dengan membuka cabang usaha di wilayah lain akan meningkatkan produksi dan cakupan wilayah pemasaran hasil industri kecil.

\section{KESIMPULAN DAN SARAN}

$\underline{\text { Kesimpulan }}$

Berdasarkan analisis SWOT potensi sector industri Kecil yang ada di Kota Tarakan peiode tahun 2016 yang lebih baik adalah dari segi kekuatan ( Strength ) dan kesempatan ( Opportunities ) dalam mengembangkan potensi yang telah dimiliki ole hmasing - masing industry kecil di Kota Tarakan.Membuat akun media social untuk mempermudah promosi dalam 
penjualan produk. Di zaman yang modern dan serbamemanfaatkan kecanggihan teknologi, media sosial yang beragam saat ini dapat dijadikan sebagai alat untuk melakukan promosi. Media social menjadi salah satu alat promosi yang efektif karena dapat secara langsung memberikan infromasi kepada pasar penjualan hasil produksi industry kecil. Membuka cabang di luar wilayah industri. Dengan membuka cabang usaha di wilayah lain akan meningkatkan produksi dan cakupan wilayah pemasaran hasil industr i $\mathrm{k}$ ecil.

$\underline{\text { Saran }}$

Diperlukan kerjasama yang baik antara pengusaha dengan pihak pemerintah dan instansi terkait dalam meningkatkan potensi unit usaha di bidangnya masing-masing.

\section{DAFTAR PUSTAKA}

Ariani.Utomo.2017. Kajian Strategi Pengembangan

Usaha Mikro Kecil dan Menengah (UMKM) Di Kota Tarakan. Jurnal Organisasi dan Manajemen , Volum e 13, Nomor 2, September 2017, $99-118$

Astamoen, I. H. 2005. Entrepreneurship . Bandung: Alfabeta.

Badan Pusat Statistik (BPS) Provinsi Kalimantan Timur.2013. Produk Domestik Regional Bruto Menurut Lapangan Usaha Provinsi Kalimantan Timur Tahun 2008 2012.Gross Regional Domestic Product by
Industrial Origin of

Kalimantan Timur. BPS

Provinsi Kalimantan Timur, Samarinda

BPS Kota Tarakan.

https://tarakankota.b

ps.go.id/2017 Analisis

Pembangunan Ekonomi

Daerah Kota Tarakan.

Diakses pada 10 Januari 2017.

Bateman, Thomas. S \& Snell, Scott A. (2008). Manajemen: kepemimpinan dan kolaborasi dalam dunia yang kompetitif . Edisi ketujuh. Jakarta: Salemba Empat.

David, Fred R. (2009). Manajemen Strategis: Konsep . Jakarta: Salemba Empat

Dumairy. 1997. Perekonomian Indonesia , Jakarta:Erlangga

Gumelar, dkk. 2015. Strategi Pengembangan Industri Kecil Kripik Tempe Di Desa Karangtengah Prandon Kabupaten Ngawi (Studi pada Dinas Koperasi, Usaha Mikro Kecil Menengah dan Perindustrian Kabupaten Ngawi). Jurusan Administrasi Publik, Fakultas Ilmu Administrasi, Universitas Brawijaya, Malang.

Irmawati S. 2015. Strategi Peningkatan Daya Saing Industri Unggulan Provinsi Jawa Tengah Untuk Menghadapi Asean Economic Community (AEC ). Skripsi . Jurusan Ekonomi Pembangunan Fakultas Ekonomi Universitas Negeri Semarang

Karmini, 2016. Daya Saing Produk Produk Industri Kecil Dan 
Menengah (Kelompok

Barang Kayu Dan Hasil

Hutan) Di Kota Tarakan.

Fakultas Pertanian,

Universitas Mulawarman

Samarinda, Kalimantan

Timur.

Lubis, H. 2007. Tinjauan teori perkuatan sentra industri kecil menengah.Dalam Membangun daya saing industri daerah dengan pendekatan kompetensi inti industri. Departemen Perindustrian, Jakarta.

Mohammad Adib. 2008. Industri Kec il Sebagai Gerakan. Rancangan Usulan Penelitian Untuk Disertasi Studi Kasus. Surabaya. Departemen Antropologi FISIP - UNAIR

Pratama Diyan, 2012. Analisis Pertumbuhan Penyerapan Tenaga Kerja Pada Industri Kecil Di Kabupaten Jepara. Skrip si .Program Sarjana Fakultas Ekonomika dan Bisnis Universitas Diponegoro.

Richard L. Daft. 2010. Era Baru Manajemen ,Edward

Tanujaya, Edisi 9. Jakarta: Salemba Empat.

Setyawan R. 2015. Penerapan Analisis SWOT Sebagai Landasan Merumuskan Strategi Pemasaran U saha Jasa Sewa Mobil “AMAN -
AMIN" Transport Tours and

Travel Ambarketawang

Sleman Yogyakarta. Skripsi

Jurusan Pendidikan Ekonomi

Fakultas Ekonomi

Universitas Negeri

Yogyakarta.

Siburian, dkk. 2013. Analisis

Penyerapan Tenaga Pada

Industri Kecil Dan Menengah

(Studi Kasus Pada Industri

Kecil dan Menengah

Furniture Kayu di Kabupaten

Jepara). Jurusan IESP

Fakultas Ekonomika dan

Bisnis Universitas

Diponegoro Semarang.

Thoha, Mahmud. 1998. Dampak

Persetujuan Putaran Uruguay

- GATT terhadap Industri

Kecil,Universita s Indonesia (UI - PRESS).

Vina Prasa Fitragusi, 2014. Analisis Deskriptif Perilaku

Kewirausahaan pada

Pengusaha Industri Mochi di

Kota Sukabumi.Universitas

Pendidikan Indonesia.

Yusupharis. 2014. Berkembangnya

Industri Kecil Terhadap Perekonomian Indonesia. (https://mohyusupharis.word press.com/2014/06/11/berke mban gnya - industri - kecil terhadap - perekonomian indonesia/ ).Diakses pada tanggal 23 September 2017 